\title{
Degradation of archaeological horn silver artefacts in burials
}

\author{
Geraldine Marchand ${ }^{1}$, Elodie Guilminot ${ }^{1 *}$, Stéphane Lemoine', Loretta Rossetti ${ }^{1}$, Michelle Vieau ${ }^{1}$ \\ and Nicolas Stephant ${ }^{2}$
}

\begin{abstract}
Background: Archaeological silver objects from burial sites are of a grey-lavender aspect. The formation of $\mathrm{AgCl}$ leads to an increase in the volume of the objects, which may undergo a complete transformation into corrosion products. This degradation process has been little studied to date. In this paper, eight horn silver objects were studied by SEM and XRD.

Results: Analyses showed a corrosion system composed of bi-layers: a compact inner layer and a porous outer layer. Corrosion products were mainly silver chlorides $(\mathrm{AgCl})$, chlorargyrite. Some objects displayed copper inclusions both in the metallic core and in the inner layer. Highly mineralized objects contained other oxygen-rich phases (with Si, Ca) in the inner layer. Soil markers were detected in the outer layer.

Conclusion: Based on these results, we put forward a corrosion mechanism for horn silver objects. Silver chloride is formed by the disappearance of the initial silver oxide layer. This AgCl layer is not protective and supports ion transport. Thus an outer layer of silver chloride, incorporating soil markers, is formed.
\end{abstract}

Keywords: Horn silver, Archaeological objects, Original surface, Inner/outer corrosion layer, SEM-EDS analysis

\section{Introduction}

Silver was one of the first metals to be used by humans, and is found in many archaeological objects such as coins, jewellery and ornaments [1]. Silver was often alloyed with copper to enhance its mechanical properties. The best known $\mathrm{Ag}-\mathrm{Cu}$ alloy is sterling silver (92.5wt\% Ag / 7.5wt\% Cu), which was commonly used for coins. Its degradation process is well known. Because of low copper solubility in silver, copper-silver alloys are composed of a silver-rich phase and a copper-rich phase [1]. Alteration of this copper-rich phase causes the formation of green corrosion products on the silver object [2-4]. We find pure silver in many precious objects, like jewellery, which are often stored indoors in locations such as museums or churches. The degradation of these objects depends on the presence of pollutants in the atmosphere, a phenomenon which has been widely studied. The atmospheric corrosion of old silver causes a thin film of tarnish to appear [1,5-7]: these black

\footnotetext{
* Correspondence: elodie.guilminot@arcantique.org

'EPCC Arc'Antique, 26 rue de la Haute Forêt, 44300 Nantes, France Full list of author information is available at the end of the article
}

corrosion products are formed by sulfur pollutants such as hydrogen sulfide $\left(\mathrm{H}_{2} \mathrm{~S}\right)$ and carbonyl sulfide (OCS). The corrosion layer is mainly composed of silver sulfide $\left(\mathrm{Ag}_{2} \mathrm{~S}\right)$.

The deterioration of archaeological objects from marine environments leads to the formation of thick layers of corrosion products and concretions [3]. The mixture of corrosion products frequently separates into two layers. The inner layer extends from the residual metal core to the original surface and does not contain calcareous or seabed materials. The outer layer extends from the original surface out onto the surrounding media. Concretion (a mixture of organic and inorganic calcite and aragonite $\left.\left(\mathrm{CaCO}_{3}\right)\right)$ is often only weakly bonded to the corrosion product layer [3]. In marine silver artefacts, the main corrosion products are silver chloride $\mathrm{AgCl}$, silver sulphide $\mathrm{Ag}_{2} \mathrm{~S}$ and mixed silver chloride and bromide $\mathrm{AgCl} / \mathrm{Br}$. In aerobic conditions, concretions tend to protect silver artefacts. In anaerobic conditions, the main corrosion product is silver sulphide [3].

When silver objects have remained underground for a long period of time, a mineralization process also occurs. Generally, silver is corrosion resistant. Silver adsorbs 
molecules of oxygen which are partially converted into oxygen ions $\left(\mathrm{O}^{2-}\right)$. Combination between metal cations and oxygen ions should result in the formation of an oxide (generally $\mathrm{Ag}_{2} \mathrm{O}$ ) [8]. Silver oxide is outstandingly protective. When humidity is high, more than two layers of adsorbed water are present and electrochemical reactions take place. According to the Pourbaix diagram [9], $\mathrm{Ag}_{2} \mathrm{O}$ is stable in mildly acid, neutral and basic solutions. However, chloride and sulfide ions tend to enlarge crystalline defects [8]. Chloride, sulphur and oxygen were detected in a Roman silver artefact buried in soil [10]. In a chloride rich environment, the objects can be completely transformed into $\mathrm{AgCl}$. The presence of $\mathrm{AgCl}$ is always associated with horn silver. Horn silver objects are stable and are of a greyish aspect $[2,11]$. In the presence of sulfate-reducing bacteria, silver objects contain silver sulfide $\left(\mathrm{Ag}_{2} \mathrm{~S}\right)$ and chlorides $(\mathrm{AgCl})$ [12,13]. North et al. [3] explained this phenomenon by the alternative exposure of an object in a chloride rich environment to an aerobic $(\mathrm{AgCl})$ and anaerobic $\left(\mathrm{Ag}_{2} \mathrm{~S}\right)$ environment. In the case of typical archaeological silver objects found in burial sites, the main corrosion products are silver chlorides [2,12,14-17]. Silver chloride forms a brittle, finely granular layer. However, unfavourable conditions will result in an object being completely converted into silver chloride. Certain soil components ( $\mathrm{Ca}, \mathrm{K}, \mathrm{Al}, \mathrm{Si}, \mathrm{P} . .$. interact with metal corrosion products [14]. The formation of chlorargyrite $(\mathrm{AgCl})$ in burial environments is still poorly understood [18]. The types and mechanisms of metallic silver embrittlement were explained by R. Wanhill [17,19-22]. However, for horn silver corrosion there is only a German study from 1979 [2].

The objective of this work is to examine the corrosion products of archaeological horn silver objects from burial sites. Several objects were available for this study. The metallic core and the corrosion layer were characterized by using a scanning electron microscope (SEM) and energy-dispersive X-ray spectroscopy (EDS). Based on these observations, the corrosion mechanisms of horn silver will be presented.

\section{Materials and methods}

\section{Archaeological samples}

The first sample (S1) consists of corrosion products from a late Roman fibula, from Cholet Museum (France). Figure 1 shows the brooch being restored: the engraved decoration is obscured by corrosion products. Archaeological samples (S2 to S7) are silver jewels from Saint Martin's Church, in Angers (France). They all originate from a single burial site, dating from the early Middle Ages $\left(5^{\text {th }}-7^{\text {th }}\right.$ century). Figure 2 shows X-ray radiography of the objects. This technique reveals object details despite the presence of sediments. The final sample

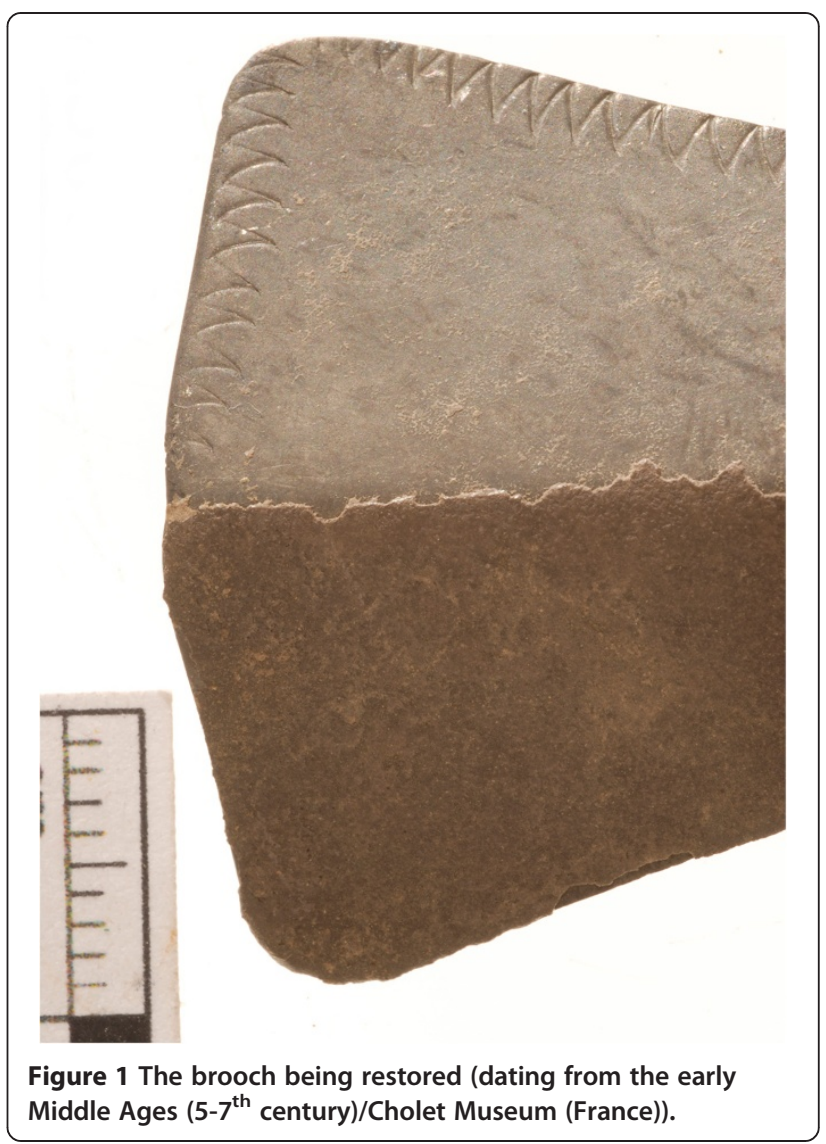

(S8) is a small spiral rod from the Gallo-Roman archaeological site of Rezé (Nantes, France). Samples were taken from each object so as to contain the complete stratigraphy (corrosion products and metal core if still present) (Table 1).

Samples were embedded in an epoxy cold mounting resin, and polished with series of silicon carbide papers up to 4000 grit and $1 \mu \mathrm{m}$ diamond paste. After polishing, samples were stored in a desiccator.

\section{Morphology observation and composition analysis}

First, samples (S2 - S8) were examined by a Zeiss optical microscope with a $50 \times$ magnification objective lens. A Scanning Electron Microscope (SEM) (JEOL JSM5800LV $15 \mathrm{kV}$ or Stereoscan $440-20 \mathrm{kV}$ ) was used to observe the morphology of corrosion products, and Energy Dispersive X-ray Spectroscopy (EDS) was used to elucidate elemental composition.

Corrosion products of the brooch (S1) were analyzed by X-ray Diffraction (XRD) with diffractometer (X'Pert pro PANalytical) using $\mathrm{Cu} K \alpha_{1}$ and $K \alpha_{2}$ (40 V and 40 $\mathrm{mA})$ in $2 \Theta$ configuration. Sample $\mathrm{S} 2$ was analyzed at C2RMF (Centre de Recherche et de Restauration des Musées de France, Louvre Laboratory) by $\mu$-XRD with a Rigaku microma×002 tube, a Kirchpatrick-Baez optical 


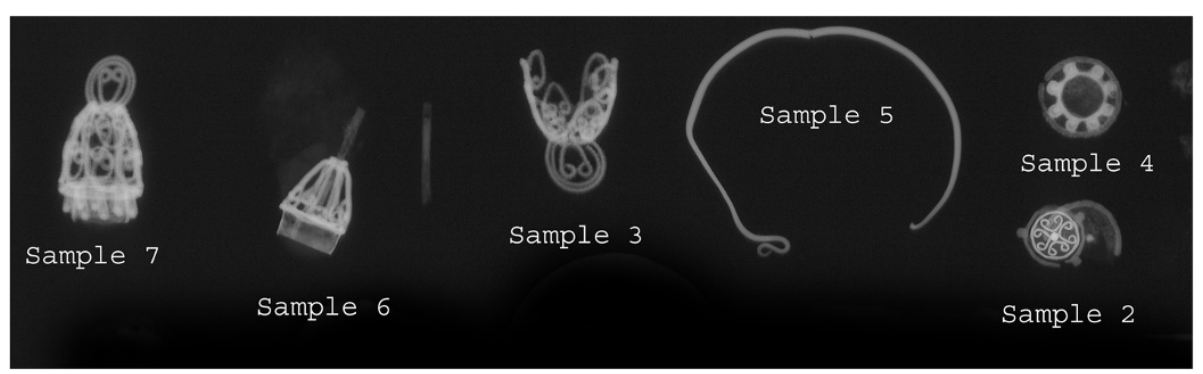

Figure $2 \mathrm{X}$-ray photography of the objects (S2 to S7).

and a 2D R-Axis IV detector $(45 \mathrm{kV}, 660 \mu \mathrm{A}$ for an incident beam of $200 \mu \mathrm{m}$ ).

\section{Results}

\section{Sample S1: corrosion products}

Figure 3 shows an XRD spectrum of corrosion products in sample S1. The main compound is chlorargyrite $(\mathrm{AgCl})$. Metallic silver was also detected.

\section{Sample S5: silver alloys}

Green corrosion products are present on sample S5. SEM-EDS analyses show the presence of 3 phases in the metallic core: a copper-rich phase $(85 \mathrm{at} \% \mathrm{Cu}, 10 \mathrm{at} \% \mathrm{Zn}$, 5at\% Ag), a silver-rich phase (85at\% $\mathrm{Ag}, 12 \mathrm{at} \% \mathrm{Cu})$ and an oxygen-rich phase (57at\% O, 10at\% Zn, 5at\% Ag). These green corrosion products are probably due to copper corrosion. As sample S5 is an $\mathrm{Ag} / \mathrm{Cu}$ alloy, it will not be used in the study of horn silver corrosion.

\section{Samples S2, S3 and S4: samples without metallic core} In samples S2 and S4, the metallic core is entirely corroded. In both samples, copper was detected in the mineralized core: its level is of 2 at $\%$ in sample 52 , and varies

Table 1 Description of samples

\begin{tabular}{|c|c|c|c|}
\hline Sample & Object & Description & Analysis \\
\hline S1 & $\begin{array}{l}\text { Horn silver } \\
\text { brooch }\end{array}$ & Corrosion products & $X R D$ \\
\hline S2 & $\begin{array}{l}\text { Horn silver } \\
\text { jewel }\end{array}$ & $\begin{array}{l}\text { Corroded object, no } \\
\text { metallic core }\end{array}$ & $\begin{array}{l}\text { OM, EDS-SEM, } \\
\text { MXRD }\end{array}$ \\
\hline S3 & $\begin{array}{l}\text { Horn silver } \\
\text { jewel }\end{array}$ & $\begin{array}{c}\text { Metallic core is partially } \\
\text { present }\end{array}$ & OM, EDS-SEM \\
\hline S4 & $\begin{array}{l}\text { Horn silver } \\
\text { jewel }\end{array}$ & $\begin{array}{l}\text { Corroded object, no } \\
\text { metallic core }\end{array}$ & OM, EDS-SEM \\
\hline S5 & $\begin{array}{l}\text { Horn silver } \\
\text { earring }\end{array}$ & $\begin{array}{l}\text { Presence of green } \\
\text { corrosion products }\end{array}$ & OM, EDS-SEM \\
\hline S6 & $\begin{array}{l}\text { Horn silver } \\
\text { earring }\end{array}$ & $\begin{array}{c}\text { Presence of a metallic } \\
\text { core }\end{array}$ & OM, EDS-SEM \\
\hline S7 & $\begin{array}{l}\text { Horn silver } \\
\text { earring }\end{array}$ & $\begin{array}{c}\text { Presence of a metallic } \\
\text { core }\end{array}$ & OM, EDS-SEM \\
\hline S8 & $\begin{array}{l}\text { Horn silver small } \\
\text { spiral rod }\end{array}$ & $\begin{array}{c}\text { Presence of a metallic } \\
\text { core }\end{array}$ & OM, EDS-SEM \\
\hline
\end{tabular}

between 2 and 12at\% in samples S3 and S4. SEM pictures using backscattered mode (Figures 4 and $5 \mathrm{a}$ ) show the presence of two phases in the mineralized core (dark and light phases). The dark phase contains a high concentration of oxygen and little or no chloride: 55-65at\% O, 10-15at\% Ag, 10-20at\% Si and 15-20at\% Ca (for S2, S3 and S4). In sample S2, the dark phase has been analyzed by $\mu$ XRD. Silver oxides have not been detected; the crystalline phase identified is calcite $\left(\mathrm{CaCO}_{3}\right)$. In samples $\mathrm{S} 2, \mathrm{~S} 3$ and S4, the light phase contains a greater quantity of both silver and chlorides: 55-60at\% Ag, 30at\% Cl, 10$15 \mathrm{at} \% \mathrm{O})$. This light phase is found in the core and near the original surface (Figure 4). The light phase constitutes the layer which lies immediately below the original surface, and will be referred to henceforth as the inner layer. We also find corrosion products above the original surface, which constitute the outer layer. The composition of the outer layer and inner layer is different. The outer layer contains a higher proportion of chlorides: $45 \mathrm{at} \% \mathrm{Ag}, 45 \mathrm{at} \% \mathrm{Cl}$. The corrosion products are probably composed of chlorargyrite $(\mathrm{AgCl})$. Another difference between the inner layer and outer layer is porosity, the outer layer being more porous than the inner layer.

\section{Samples S3, S6, S7, S8: samples with metallic core}

Other samples (S3, S6, S7 and S8) contain a metallic core (Figure $5 \mathrm{~b}$ ). These metallic cores are encased in an inner layer and outer layer of corrosion products. As in previous samples (S2 and S4), the inner layer is denser than the outer layer (Figure 6a). SEM-EDS analysis indicates a high silver content the in metallic cores: sample S3 contains about 5 at\% Cu; sample S6 has 3-4at\% Cu; sample $\mathrm{S} 7$ contains about 3 at\% $\mathrm{Cu}$ and inclusions with Fe and Mg; in sample S8, we detected only traces of $\mathrm{Cu}$ : the silver is very pure.

The metallic core may be partially oxidized, probably due to the development of corrosion. In sample S8, the inner layer is not homogeneous; some areas are not corroded because corrosion products develop more readily in given directions (Figure 6b). Corrosion appears to follow slip lines due to hardening. During the manufacturing process, this object (a spiral rod) underwent torsions 


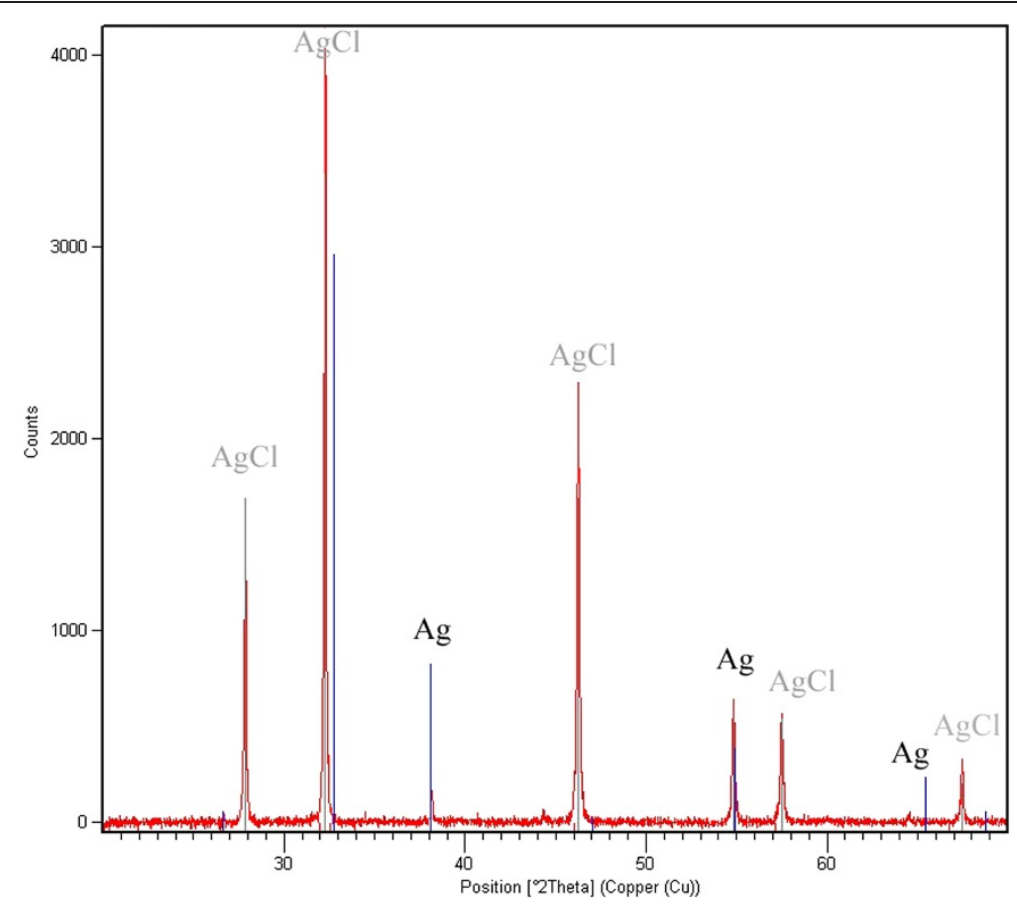

Figure 3 XRD spectrum of corrosion products collected on the horn silver brooch (S1).

causing it to harden. In sample S8, the inner layer contains mainly silver chlorides, and may be very fragile. In sample S3, S6 and S7 from another archaeological site, the inner layer mainly contains $\mathrm{Ag}, \mathrm{Cl}$ and $\mathrm{O}$. The high concentration of oxygen is always associated with other elements ( $\mathrm{Ca}$ in $\mathrm{S} 3$; $\mathrm{Si}$ and/or $\mathrm{Cu}$ in $\mathrm{S} 6$ and $\mathrm{S} 7$ ). We also detected copper in the corrosion layer.

In all samples (S3, S6, S7 and S8), the outer layer contains mainly silver chlorides. There are also soil markers (sediments: Al, Si, Fe ...). Sediments can also form a thick layer on top of the outer layer (Figure 6a). The original surface is located between the inner dense layer and the outer porous layer. This localization is confirmed by the detection of the weld or of gilding: in sample $\mathrm{S} 3$, we were able to find the weld metal $(\mathrm{Sn} / \mathrm{Pb})$ on the original surface; in sample $\mathrm{S6}$, a thin gold layer was detected on the original surface, which may correspond to gilding.

\section{Discussion}

\section{Summary of results}

Results show that all objects display the same type of corrosion (Figure 7). The original surface is located between the inner layer and the outer layer. This localization of the original surface has already been reported by MacLeod and North [3]. They also observed that cleavage between these layers was good, but failed to explain this phenomenon. This is in fact due to the variation in porosity between the layers. The outer layer is porous and is mainly composed of silver chlorides $(\mathrm{AgCl})$ together with sediments (soil markers). The inner layer is denser and incorporates inclusions such as $\mathrm{Cu}$. It generally consists of a silver chloride $(\mathrm{AgCl})$ mixture and other phases containing oxygen. These oxygen-containing phases were not clearly identified as they are always associated with other elements $(\mathrm{Ca}, \mathrm{Si}$ or $\mathrm{Cu})$. Calcite $\left(\mathrm{CaCO}_{3}\right)$ was detected in the dark phase of sample S2. Silicates and copper oxides may also be found, although the presence of silver oxides has never been proved. In sample S8, the inner layer is composed of silver chlorides only. This variation between S8 and the other samples can be explained by the difference in burial environments: objects S2, S3, S4, S5, S6 and S7 come from Saint Martin's Church, whereas object S8 comes from the Gallo-Roman site of Rezé. MacLeod and North [3] have already referred to the connection between the formation of the corrosion products mixture $(\mathrm{AgCl}$ and $\mathrm{Ag}_{2} \mathrm{~S}$ ) and variations in the environment (anaerobic/ aerobic). In our case, we did not detect $\mathrm{Ag}_{2} \mathrm{~S}$ but a mixture of $\mathrm{AgCl}$ and another, difficult to identify, oxygen-rich phase. A better knowledge of this phase is essential to confirm the absence of silver oxides. Since AgCl formation requires the absence of silver oxides [23], it would seem unlikely that this dark phase contains silver oxides. This phase becomes more important when the object is completely corroded. Figure $6 \mathrm{~b}$ shows a schematic diagram of corrosion with a metal core, but it can also be extended to completely corroded objects: in some objects (S2, S3 and S4), the inner layer has developed to the extent that the 


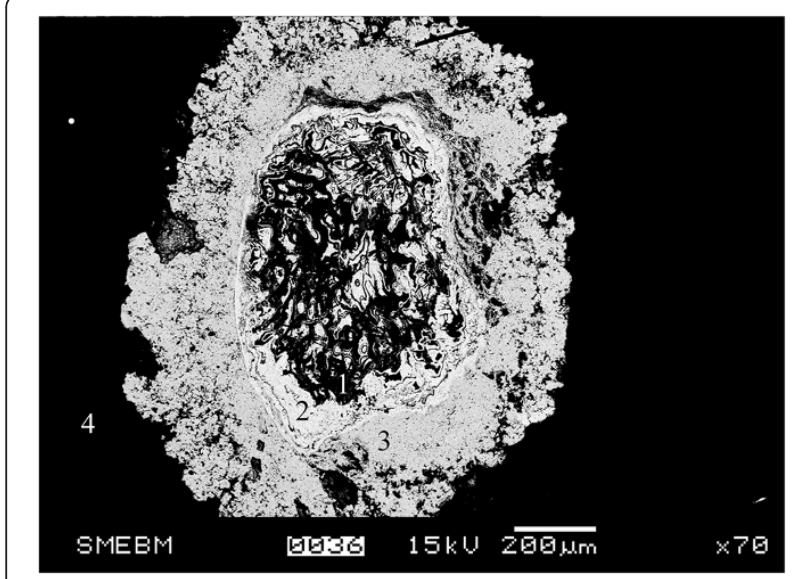

Figure 4 SEM Picture in BSE (BackScattered Electron) of sample S2 (1: dark phase in mineralized core, 2: light phase in the inner layer, 3: outer layer, 4: resin).

metal core has completely disappeared. Object S3 presents both profiles: the first sample taken from the object is completely mineralized (Figure 5a); whereas in another sample, the object still displays a metallic core (Figure 5b). When the metallic core is completely mineralized, the outer layer is much thicker: in Figure 5a, the outer layer measures about $250 \mu \mathrm{m}$; on Figure $5 \mathrm{~b}$, the outer layer is about $30-50 \mu \mathrm{m}$. We also observe that the oxygen-rich dark phase (with $\mathrm{Ca}, \mathrm{Si}$ and $\mathrm{Cu}$ ) is detected only in the mineralized core. Copper comes from inclusions in the metal and copper oxides are formed by galvanic coupling. Si and $\mathrm{Ca}$ elements were not detected in the metallic core of sample S3 in contrast to the mineralized core. This difference shows that the origin of these elements is not due to the manufacturing process but to the burial environment.

\section{Proposal for the corrosion mechanism}

The formation of $\mathrm{AgCl}$ has been investigated by many scientific papers, but in other media and under different conditions. The formation of $\mathrm{AgCl}$ on silver electrodes has been specifically studied in chloride media [24-26]. Formation of the first layer follows an adsorptiondesorption mechanism, then a thin film of $\mathrm{AgCl}$ grows due to diffusion. As the $\mathrm{AgCl}$ film is discontinuous, ion transport takes place via spaces between grains of $\mathrm{AgCl}$. As the film thickens, the spaces between the $\mathrm{AgCl}$ grains close up and the ion transport occurs mainly via microchannels running through the $\mathrm{AgCl}$ grains [24]. In these studies [24-26], the thickness of the $\mathrm{AgCl}$ layer is of the order of tens of $\mu \mathrm{m}$, and $\mathrm{Ag}+$ ions are produced by the anodic potential. The formation of $\mathrm{AgCl}$ on archaeological silver objects occurs under different conditions. Accelerated corrosion tests were conducted to study the corrosion film observed on archaeological objects [14,23], but these standard test samples also had a fine layer of
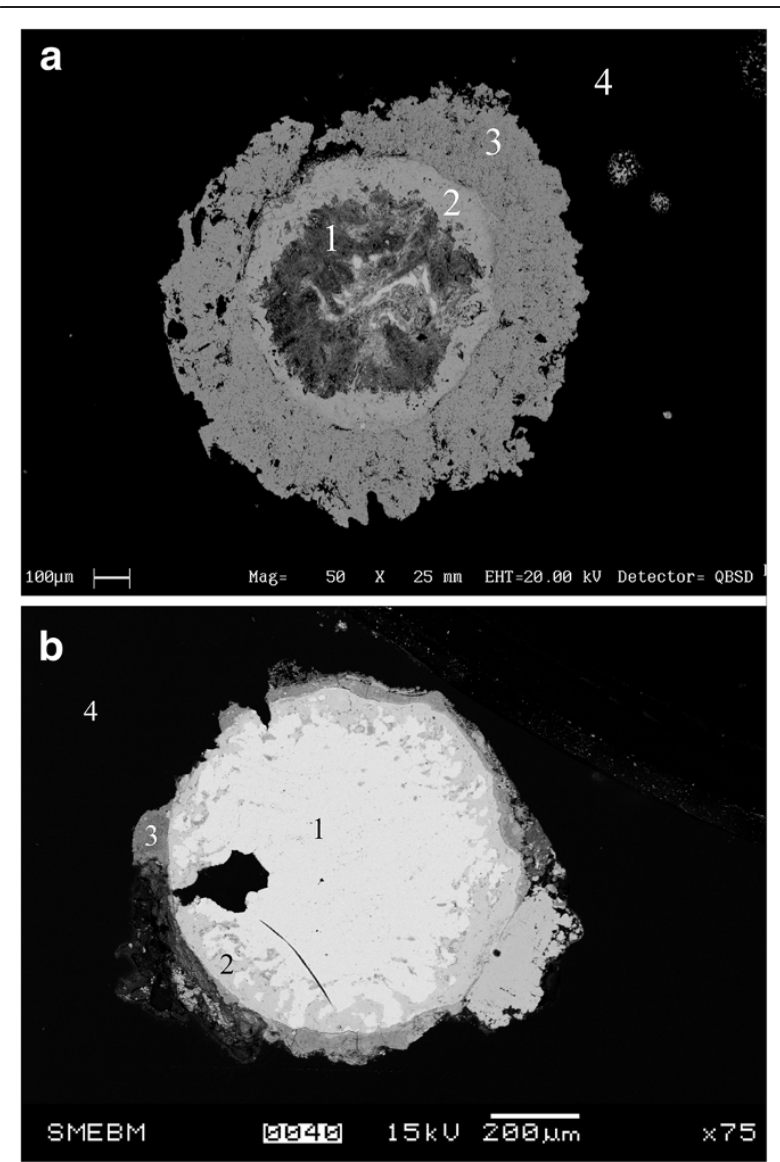

Figure 5 SEM Picture in BSE (BackScattered Electron) of sample S3: a- (1: dark phase in mineralized core, 2: light phase in the inner layer, 3: outer layer, 4: resin); b- the entire sample (1: metallic core, 2: inner layer, 3: outer layer, 4: resin).

corrosion products. Removing the protective oxide film is necessary to support the formation of silver chloride. In our analysis, we did not identify the presence of $\mathrm{Ag}_{2} \mathrm{O}$. Jaro M. [27] suggested that in burial conditions (e.g. in crypts or graves), ammonia dissolves silver oxides, and silver ions react to form silver chloride, chlorargyrite (AgCl). Organic decomposition products (ammonia, nitrates, acetic acid, $\mathrm{H}_{2} \mathrm{~S}$ ) favour the initial corrosion process [6]. Silver chloride does not create a protective layer, thus the metal can be completely transformed into silver chloride.

Horn silver has bilayer films that correspond to the corrosion process as identified by Payer et al. [28]. A generalized model for this corrosion system is presented for metals in chloride solutions. Corrosion products form 2 layers: a porous outer and a compact inner layer. According to Payer's model, corrosion is initiated by the protective layer becoming non-protective. In the case of horn silver we examine, it is thought that ammonia may have destroyed the silver oxides in the burial environment [27]. This new non-protective layer then becomes an inner 

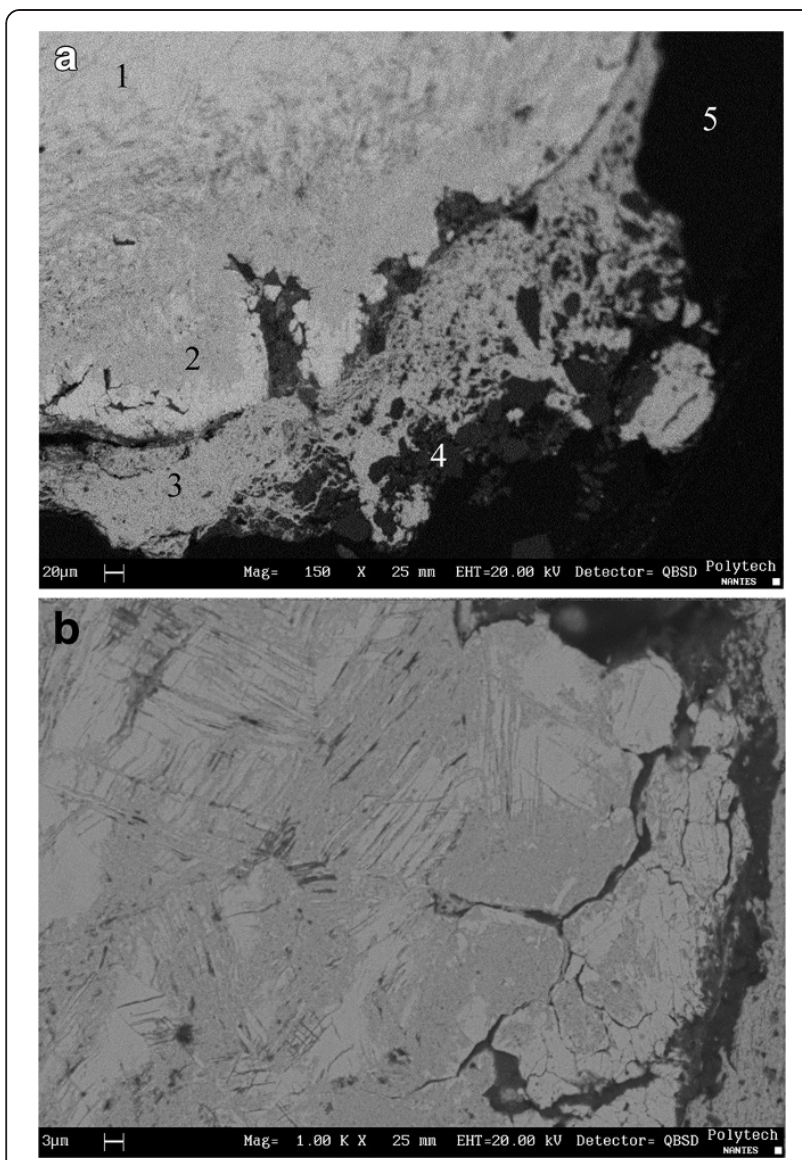

Figure 6 SEM Picture in BSE (BackScattered Electron): a- sample S8 (1: metallic core, 2: inner layer, 3: outer layer, 4: sediment, 5: resin); b- zoom on the inner layer. layer. A thicker outer layer then develops through the precipitation of soluble species (e.g. sediments) and further reaction of corrosion products $(\mathrm{AgCl})$. The porous outer layer can permit the penetration of water and the diffusion of $\mathrm{Cl}$. Cations are produced by the oxidation of metal at the metal/inner layer interface. High ion transport in the inner layer allows for the growth of corrosion films: $\mathrm{Ag}^{+}$ cations diffuse to the outer layer, and $\mathrm{Cl}^{-}$anions diffuse to the inner layer.

Copper inclusions do not seem to modify the corrosion mechanisms of horn silver. When copper is an alloying element (Sample S5), copper corrosion products are found in the corrosion layers. Otherwise copper inclusions are found only in the inner layer (and in the dark phase). Copper may play a local protective role through galvanic coupling. However, pure silver samples, such as S8, or samples with 2-5at\% copper are subject to the same corrosion system: a compact inner layer and a porous outer layer of $\mathrm{AgCl}$.

\section{Conclusions}

Horn silver artefacts have a specific corrosion system: the surface is deformed by dull grey corrosion products. The objects are weakened and sometimes entirely mineralized. Artefacts displaying this corrosion system are few and far between because the corrosion process requires specific conditions. The opportunity to analyze and observe several horn silver objects is exceptional. We studied the different layers of corrosion products and formulated a corrosion process. The inner layer is formed with chloride by the disappearance of initial silver oxide layer. This $\mathrm{AgCl}$ layer is not protective and there is a high level of ion transport. Below the original surface, the inner layer is compact and contains other oxygen-rich phases. Above the original surface, silver chloride precipitates in the porous and larger outer layer;

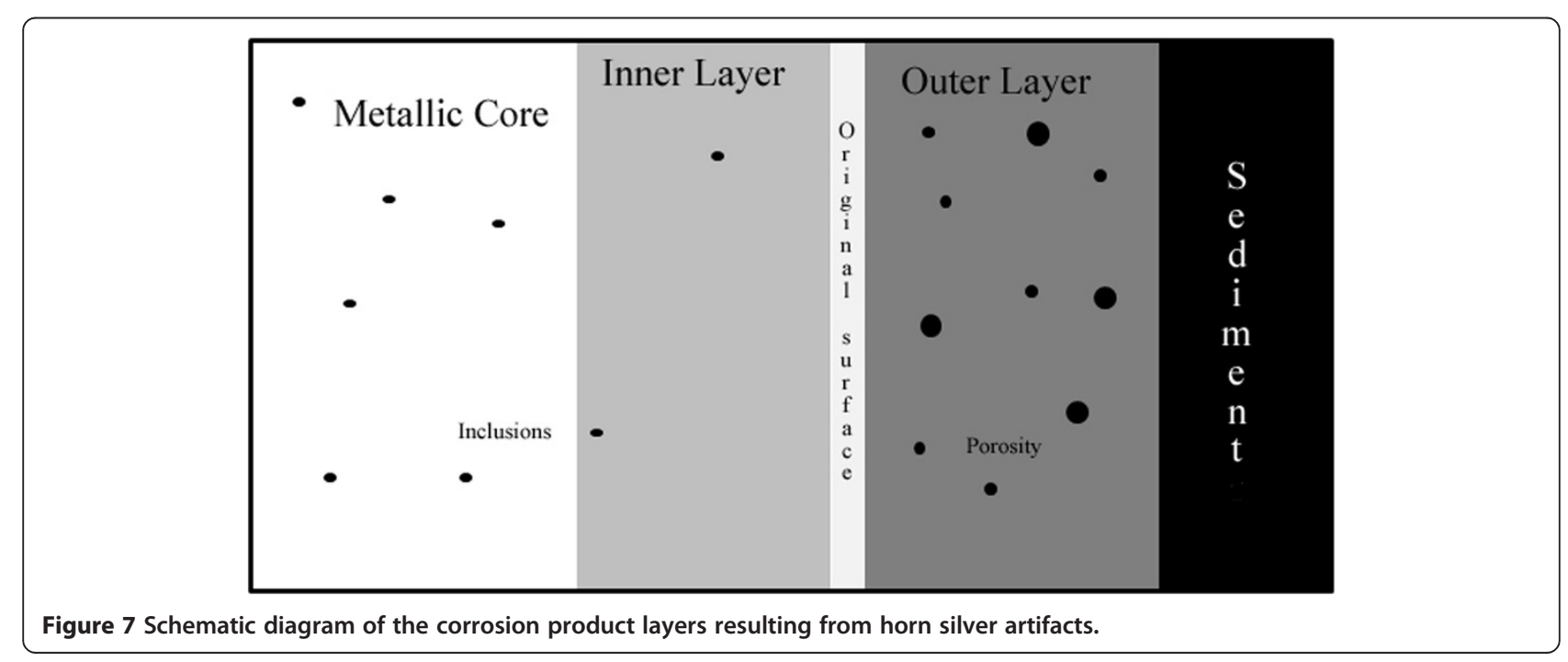


it incorporates soil markers. The difference in porosity between the outer and inner layers ensures good cleavage on the original surface.

\section{Competing interests}

The authors declare that they have no competing interests.

\section{Authors' contribution}

Geraldine Marchand: she made analyzes and experiments. Elodie Guilminot: she supervised Marchand's work, and she drafted the manuscript. Stéphane Lemoine: he worked on the archaeological horn silver objects. Loretta Rossetti: she worked on the archaeological horn silver objects. Michelle Vieau: she worked on the archaeological horn silver objects. Nicolas Stephant: he participated in the SEM photos. All authors read and approved the final manuscript.

\section{Acknowledgements}

The authors would like to express their gratitude to archaeologists, Daniel Prigent and Marie-Laure Hervé, for providing horn silver artifacts. We also wish to thank Francois Mirambet for his $\mu$-XRD analysis. We are very grateful to Clémence Cauvin, the student who participated in this work.

\section{Author details}

'EPCC Arc'Antique, 26 rue de la Haute Forêt, 44300 Nantes, France. 'Université de Nantes, Institut Jean Rouxel (IMN), 2 rue de la Houssinière, BP 92208, 44322, Nantes cédex 3, France.

Received: 6 September 2013 Accepted: 12 February 2014 Published: 24 February 2014

\section{References}

1. Selwyn L: Silver. In Metals and Corrosion, a handbook for the conservation professional. Edited by Canadian Conservation Institute. Ottawa; 2004:131-140.

2. Raub C: Chemische und Untersuchungen Metallkundliche un aus den Metallfunden Königsgräbern von Es Soumaa und Siga. In Die Numider Edited by Horn HG, Rüger CB. Bonn; 1979:363-375.

3. North NA, MacLeod ID: Corrosion of Metals. In Conservation of Marine Archaeological Objects. Edited by Butterworths, Pearson. Canberra; 1987:91-95.

4. Aguas H, Silva RJC, Viegas M, Pereira L, Fortunato E, Martins R: Study of environmental degradation of silver surface. Phys Status Solidi C 2008, 5:1215-1218.

5. Franey JP, Kammlott GW, Graedel TE: The corrosion of silver by atmospheric sulfurous gases. Corros Sci 1985, 25:133-143.

6. Costa V: The deterioration of silver alloys and some aspects of their conservation. Rev Conserv 2001, 2:18-31.

7. Evesque $\mathrm{M}$, Keddam $\mathrm{M}$, Takenouti $\mathrm{H}$ : The formation of self-assembling membrane of hexadecane-thiol on silver to prevent the tarnishing. Electrochim Acta 2004, 49:2937-2943.

8. Novakovic J, Vassiliou P: Corrosion of Silver Alloy Artefacts in Soil. In Proceedings of the International Conference on Conservation Strategies for Saving Indoor Metallic Collections with a Special Section on Legal Issues in the Conservation of Cultural Heritage. Edited by Argyropoulos V. Cairo: TEl of Athens; 2007:58-63.

9. Pourbaix M: Argent. In Atlas d'équilibres Electrochimiques à $25^{\circ} \mathrm{C}$. Edited by Gauthier-Villars. Paris; 1963:396.

10. Vanickova J, Ded J, Bartuska P, Lejcek P: Intergranular failure of roman silver artefacts. Mater Sci Forum 2007, 567-568:213-216.

11. Plenderleith HS: Argent. In The Conservation of Antiquities and Works of art. Treatment, Repair and Restoration. Edited by Oxford University Press. London; 1966:231-247.

12. McNeil M, Little B: Corrosion mechanisms for copper and silver objects in near-surface environments. J Am Inst Conserv 1992, 31:355-366.

13. MacLeod I, North N: Conservation of corroded silver. Stud Conserv 1979, 24:165-170.

14. Ingo GM, Balbi S, De Caro T, Fragala I, Angelini E, Bultrini G: Combined use of SEM-EDS, OM and XRD for the characterization of corrosion products grown on silver roman coins. Appl Phys A 2006, 83:623-629.

15. Ingo GM, Balbi S, De Caro T, Fragala I, Angelini E, Bultrini G: Microchemical investigation of Greek and Roman silver and gold plated coins: coating techniques and corrosion mechanisms. Appl Phys A 2006, 83:623-629.
16. Vassiliou P, Novakovic J, Ingo GM, De Caro T: Corrosion of Ancient Silver Alloys. In Proceedings of $17^{\text {th }}$ International Corrosion Congress, Corrosion Control in the Service of Society. Edited by NACE. Las Vegas; 2009:12.

17. Wanhill R: Embrittlement in archaeological silver artifacts: diagnostic and remedial techniques. J Min Mat S 2003, 55:16-19.

18. Bozzini B, Giovannelli G, Mele C, Brunella F, Goidanich S, Pedeferri P: An investigation into the corrosion of $\mathrm{Ag}$ coins from the Greek colonies of Southern Italy. Part I: an in situ FT-IR and ERS investigation of the behavior of $\mathrm{Ag}$ in contact with aqueous solutions containing 4-cyanopyridine. Corros Sci 2006, 48:193-208.

19. Wanhill R: Brittle archaeological silver: a fracture mechanisms and mechanics assessment. Archaeometry 2003, 45:625-636.

20. Wanhill R: Embrittlement of ancient silver. J Fail Anal Prev 2005, 5:41-54.

21. Wanhill R: Case histories of ancient silver embrittlement. J Fail Anal Prev 2011, 11:178-185.

22. Wanhill R: Stress corrosion cracking in ancient silver. Stud Conserv 2013, 58:41-49.

23. Gasteiger S, Eggert G: How to Compare Reduction Methods for Corroded Silver Finds. In The Proceedings of the ICOM Committee for Conservation Metals Working Group, Metal 2001. Edited by MacLeod I, Theile J, Degrigny C. Santiago; 2001:320-324.

24. Ha H, Payer J: The effect of silver chloride formation on the kinetics of silver dissolution in chloride solution. Electrochim Acta 2011, 56:2781-2791.

25. Bozzini B, Giovannelli G, Mele C: Electrochemical dynamics and structure of the $\mathrm{Ag} / \mathrm{AgCl}$ interface in chloride-containing aqueous solutions. Surf Coatings Technol 2007, 201:4619-4627.

26. Jin X, Lu J, Liu P, Tong H: The electrochemical formation and reduction of a thick $\mathrm{AgCl}$ deposition layer on a silver substrate. J Electroanal Chem 2003, 542:85-96

27. Jaro M: Re-Corrosion of Silver and Gilt Silver Threads on Museum Textiles After Treatments. In The Proceedings of the $7^{\text {th }}$ International Restorer Seminar, Conservation of Metals. Edited by Jaro M. Veszprem: National Centre of museums; 1990:95-98.

28. Payer $\mathrm{JH}$, Ball G, Rickett BI, Kim HS: Role of transport properties in corrosion product growth. Mater Sci Eng 1995, A198:91-102.

doi:10.1186/2050-7445-2-5

Cite this article as: Marchand et al:: Degradation of archaeological horn silver artefacts in burials. Heritage Science 2014 2:5.

\section{Publish with ChemistryCentral and every scientist can read your work free of charge \\ "Open access provides opportunities to our colleagues in other parts of the globe, by allowing anyone to view the content free of charge." W. Jeffery Hurst, The Hershey Company.}

- available free of charge to the entire scientific community

- peer reviewed and published immediately upon acceptance

- cited in PubMed and archived on PubMed Central

- yours - you keep the copyright

Submit your manuscript here:

http://www.chemistrycentral.com/manuscript/<smiles>c1ccccc1</smiles>

Chemistry Central 